and thirty users a night and a full-time African orderly on duty) there were in spite of this more than three hundred cases of venereal disease in three months.

Thus with an untreated heavily infected female population, and with a practically complete failure in male prophylaxis, we are up against a gigantic and grave problem. In addition, the mobilization of an army in West Africa has caused a large-scale and widespread redistribution of population with increased dissemination of these diseases. Therefore, the already vast problem is likely to increase further and further both in numbers and extent.

So far, the Colonial medical authorities find themselves unable to deal with the matter and, indeed, in many areas express themselves defeated before they have started. Postponement of facing up to this medical scourge is only making it more difficult each month that it is left, and each month the bill that will one day have to be paid mounts higher. As the Army pulls out of West Africa it will become solely the concern of the Colonial Medical Service; but by this time it will be beyond the powers of the Colonial medical officers already stationed there and of the fow clinics at present erected.

It will have to be tackled as an epidemic, with maps and mobile diagnostic and treatment centres, with teams of full-time doctors and orderlies, and with litres of penicillin, treating village by village, town by town, until slowly and surely each Colony is cleared to the extent that local hospitals could hope to deal with the residue. That, I fear, will be the only way by which venereal disease will be controlled in these Colonies; it has already gone too far for other measures to hope to succeed; but such measures are, one suspects, too Utopian at the present time.

For the present, the best line is to concentrate on making one fixed class of African reasonably cleanthat is, the educated African. Teach them in the schools, at the universities, and by all means possible, how to dislike and avoid venereal disease and provide the means by which they can get treated if they become infected. Then slowly, as the clerks, the telegraphists and the printers emerge from their technical training, they will become venereal disease conscious.

Unfortunately, one realizes only too well the immense difficulties, especially at the present time. All the same, one must wonder whether sufficient attention is paid to the question of venereal disease in West Africa.

\section{FISHERIES OF JAMAICA}

GROM April 1943 until October 1944, Dr. E. F. 1 Thompson (now on the staff of the Bingham Oceanographic Laboratory) carried out an exhaustive survey of the fisheries of Jamaica with the view of assessing their needs and making recommendations for their betterment.

In an excellent and comprehensive report*, Dr. Thompson presents convincing evidence in support of his general conclusion that so far as Jamaica is concerned "there are too many men trying to catch too few fish"; that the potential of the available fishing areas is already fully exploited, and that,

* Development and Welfare in the West Indies. Bulletin No. 18: The Fisheries of Jamaica. Report by Dr. Frnest F. Thompson. Pp. 104. (Barbados: Advocate Co., Ltd., 1945.) 30 cents. therefore, any extensive modernization and indus. trialization of the industry would lead to unemployment, increased eatching and distribution costs, and no increase in production. The recommendation is therefore made that country fishermen should be encouraged to keep or renew their contacts with agriculture, so that eventually many of them may fish chiefly as an additional and subsidiary source of income and of variation of diet for themselves and their immediate neighbours.

In recommending this policy the author points out that he is well aware that it is the reverse of that generally made by advocates of modern industrialized methods. Apparently he fears disapproval of this recommendation.

He need not do so. Only where fishing grounds are inadequately exploited can modern methods be profitably introduced. To increase fishing intensity on grounds already overfished would be reprehensible and suicidal. No better advice could be tendered than that "mixed farming become a little more 'mixed' to include some farming by coastal agriculturists", and that a proportion of fishermen be encouraged to join such communities. In fact, a counterpart of the Scottish crofter-fisherman is envisaged-a type that industrialization in Britain has now all but extinguished, and Scotland is undoubtedly the worse for it.

Progress along these lines is bound to be slow and it is pointed out that, in the meantime, the greatest need of Jamaican fishermen is more in the nature of welfare than development-perhaps the most important pronouncement in the whole of the report, and applicable not only to Jamaica but also to all other backward regions where fisheries development and similar schemes are either contemplated or already in operation.

In so far as Jamaica is concerned, the aims of such welfare work are stated to be: (1) provision of an organisation through which fishermen and their problems can be handled in a natural and orderly manner ; $(2)$ the accumulation of savings to stabilize the fishermen's living and help them to assume responsibility for their own future; (3) to organise co-operative marketing; (4) to act as a liaison between fishermen and organisations working for the social and economic betterment of the people; (5) to renew and increase fishermen's contacts with agriculture and assist about four-fifths of them to drift back to agriculture from whence they came.

Dr. Thompson is under no delusion that in Jamaica -as in all other places where such development and welfare schemes are needed-all these efforts will fail in their purpose unless right and adequate responses are stimulated in those they are designed to benefit. Whether progress be achieved by the introduction of modern methods and equipment or by other means, this hard fact must always be faced-that competitive effort must be put forth with competitive zeal, enterprise and dependability. Where these are, as he found, so sadly lacking they must be evoked and developed or the outlays of both money and effort on grandiose schemes will do no more than bring about a brief and spurious prosperity to be followed by failure, disillusionment, and distress even more acute than before. All those concerned with development and welfare projects in all parts of the world would do well to ponder carefully over the final sentence in Dr. Thompson's report, "While optimism is always welcome, careful thought should be taken lest false hopes be raised and unnecessary suffering caused". 